\title{
DETERMINATION OF CHEMICAL ELEMENTS IN AFRICANIZED Apis mellifera (HYMENOPTERA: APIDAE) HONEY SAMPLES FROM THE STATE OF PIAUÍ, BRAZIL
}

\author{
Geni da Silva Sodré \\ Universidade Federal da Bahia, Salvador - BA, Brasil \\ Luís Carlos Marchini* \\ Departamento de Entomologia, Fitopatologia e Zoologia Agrícola, Escola Superior de Agricultura "Luíz de Queiroz", \\ Universidade de São Paulo, Av. Pádua Dias, 11, 13418-900 Piracicaba - SP, Brasil \\ Orgeda Luiza Araújo Domingues Zucchi \\ Departamento de Física e Química, Faculdade de Ciências Farmacêuticas de Ribeirão Preto, Universidade de São Paulo, \\ Ribeirão Preto - SP, Brasil \\ Virgilio Franco Nascimento Filho \\ Centro de Energia Nuclear na Agricultura, Universidade de São Paulo, Piracicaba - SP, Brasil \\ Ivani Pozar Otsuk and Augusta Carolina de Camargo Carmello Moreti \\ Instituto de Zootecnia, Agência Paulista de Tecnologia dos Agronegócios, Secretaria Estadual de Abastecimento, Nova Odessa \\ - SP, Brasil
}

Recebido em 28/6/06; aceito em 30/8/06; publicado na web em 27/4/07

\begin{abstract}
Honey is a food used since the most remote times, appreciated for its characteristic flavor, considerable nutritional value and medicinal properties; however, little information exists about the presence of chemical elements in it. The objectives of this work were to determine the chemical elements present in 38 honey samples, collected directly from beekeepers from the State of Piauí, Brazil and to verify whether they presented any contamination. The chemical elements were determined by means of Total Reflection Xray Fluorescence. The means of three replicates were: $\mathrm{K}(109.671 \pm 17.487), \mathrm{Ca}(14.471 \pm 3.8797), \mathrm{Ti}(0.112 \pm 0.07), \mathrm{Cr}(0.196 \pm$ $0.11), \mathrm{Mn}(0.493 \pm 0.103), \mathrm{Fe}(1.722 \pm 0.446), \mathrm{Co}(0.038), \mathrm{Ni}(0.728 \pm 0.706), \mathrm{Cu}(0.179 \pm 0.0471), \mathrm{Zn}(0.967 \pm 0.653), \mathrm{Se}(\mathrm{not}$ detected), $\mathrm{Br}$ (not detected), $\mathrm{Rb}(0.371 \pm 0.097), \mathrm{Sr}(0.145 \pm 0.45), \mathrm{Ba}(11.681), \mathrm{Hg}$ (not detected), and $\mathrm{Pb}(0.863) \mu \mathrm{g} \mathrm{g}{ }^{-1}$.
\end{abstract}

Keywords: honey; africanized honey bee; chemical elements.

\section{INTRODUCTION}

Different chemical elements are normally found in honey; however, at high rates they are considered pollutants. Honey can become contaminated with such pollutants by means of the air, soil, and water. Therefore, analyzing chemical elements in this product can provide information with regard to its quality as food or with respect to environmental pollution ${ }^{1}$.

Accidental honey contamination comes from several sources, such as: residues of drugs used in bee disease treatment, which are administered orally, mixed with a sugar syrup and pesticide residues, particularly organochlorine and organophosphorus insecticides ${ }^{2}$. Landfills visited by bees can be sources of honey contamination by chemical pollutants.

Among the most dangerous pollutants, toxic chemical elements have been prioritized in studies. The most important are: cadmium, mercury, lead, copper, zinc, and nickel, which are present at low concentrations in the essential functions of living systems, but may become toxic when found above normal levels, depending on the type of organism exposed ${ }^{3}$. The same author has mentioned that a particular property of toxic chemical elements is that they are continually emitted from natural sources in the terrestrial and marine environments.

Tong et al. ${ }^{4}$ reported that sources of air and water pollution by toxic chemical elements and other chemical elements include industries, mining, energy generation, and automobile exhaust. According to the above mentioned authors, mining pollution in a

*e-mail: lcmarchi@esalq.usp.br particular site may be limited to one or other chemical element, but contamination by industries or from energy generation includes a large number of toxic chemical elements or a combination of these. Intolerable limits of elements emitted from fuel oil or other urban traffic sources include: aluminum, calcium, copper, iron, lead, magnesium, silicon, barium, cadmium, chromium, nickel, palladium, platinum, and others which in certain regions are detrimental to health.

Toxic chemical elements form the only group of nonbiodegradable environmental pollutants, reaching man by means of foods and consumption water. Although a fraction of the ingested amount is excreted, they possess a pronounced tendency for accumulation in man's vital organs, progressively exerting a toxic action for long periods, which also depends on their total accumulated dose, which in turn varies as a function of exposure time ${ }^{5}$.

Scientific papers using bees and their products, including analysis of chemical elements in order to monitor environmental pollution have been developed in several countries. Since 1970, honey has been proposed as an environmental indicator for pollution evaluation in areas where hives are installed ${ }^{6}$.

Brazil occupies an important position among honey producing countries, since it has a flora that is well suited for apiculture. However, information on the presence of minerals in honey composition is restricted. The State of Piauí, in the Northeast Region of Brazil, has gained projection in honey production, including organic honey producers. Thus, the present study was aimed at determining the concentrations of chemical elements present in Apis mellifera honey samples from the State of Piauí, in order to verify whether they present contamination. 


\section{EXPERIMENTAL}

Thirty-eight samples of honey produced by Apis mellifera L., 1758 (Hymenoptera: Apidae) were collected in the period from February to August 2002, directly from beekeepers of different municipalities in the State of Piauí (Pimenteiras 2 samples; Picos 35 samples; Socorro do Piauí 1 sample).

The analyses for honey chemical elements were carried out at the Apiculture Laboratory of "Departamento de Entomologia, Fitopatologia e Zoologia Agrícola of Escola Superior de Agricultura Luiz de Queiroz", Campus of "Universidade de São Paulo" (ash determination) and at the Nuclear Instrumentation Laboratory of "Centro de Energia Nuclear na Agricultura/Universidade de São Paulo", in Piracicaba, State of São Paulo, Brazil.

Initially, honey ash was obtained by burning approximately 10 $\mathrm{g}$ of the sample in a porcelain crucible by calcination in a muffle at $550{ }^{\circ} \mathrm{C}$ until constant weight; ash percentage was thus calculated ${ }^{7}$.

The ash samples were submitted to wet digestion ${ }^{8}$ in an open system using $\mathrm{HNO}_{3} / \mathrm{H}_{2} \mathrm{O}_{2}\left(\mathrm{t}=130 \pm 5{ }^{\circ} \mathrm{C}\right)$. After obtaining a clear solution, the volume was completed to $10 \mathrm{~mL}$ with deionized water. Ten $\mu \mathrm{L} \mathrm{Ga}$ (internal standard, $1000 \mu \mathrm{g} \mathrm{mL}^{-1}$ ) were added to a volume of $1 \mathrm{~mL}$ of this solution. A $20 \mu \mathrm{L}$ aliquot was pipetted onto the center of a Lucite disc ( $3 \mathrm{~cm}$ in diameter) and dried under the action of infrared light. The samples were prepared with three replicates and detected in an X-ray spectrometer for $300 \mathrm{~s}$.

\section{Data analysis}

The data were processed using $\mathrm{SAS}^{9}$; the means (three replicates), confidence interval, and multivariate analysis were thus obtained.

Analysis of principal components was used to evaluate the importance of each chemical element studied on total available variation ${ }^{10}$. This technique is based on the standardization and rotation of orthogonal axes (chemical elements), generating a new set of coordinates (principal components) not correlated among themselves ${ }^{11}$. Highly correlated characters were discarded, using the criterion proposed by Joliffe ${ }^{12}$, disregarding the variable with the highest coefficient in each component with an eigenvalue lower than 0.70 .

The mean Euclidean distance and the UPGMA method (unweighted pair-group average) from the standardized data were used in the cluster analysis ${ }^{13}$.

\section{RESULTS AND DISCUSSION}

The values corresponding to the chemical element concentrations analyzed in 38 samples of honey produced by Apis mellifera, from different municipalities in the State of Piauí are presented in Table 1 and the botanical origin of them, in the Table 2 .

Most mean values for chemical elements obtained in honey samples from the State of Piauí conform to Brazilian law ${ }^{14,15}$ (Tables 1 and 3). However, samples that do not conform to Brazilian law (samples nos. 4, 18, 24, 29, and 37) can be observed in Table 1.

In the present study, a variation from 0.038 to $0.412 \mu \mathrm{g} \mathrm{g}^{-1}$ was verified for the element $\mathrm{Cr}$, and it was observed that $13.15 \%$ of samples (samples numbers. 4, 18, 24, 29, and 37) are above the established value, since Brazilian law has set a maximum value of $0.10 \mu \mathrm{g} \mathrm{g}^{-1}$. Morse and Lisk ${ }^{16}$ analyzed honey samples from several different countries and verified $\mathrm{Cr}$ values ranging from 0.843 to $2.67 \mu \mathrm{g} \mathrm{g}^{-1}$; Caroli et al. ${ }^{6,17}$, on the other hand, found in Italian honeys, values between 1.03 and $3.93 \mu \mathrm{g} \mathrm{g}^{-1}$, which are well above those found in the present study.

For element $\mathrm{Ni}$, a value of $7.19 \mu \mathrm{g} \mathrm{g}^{-1}$ was verified in one sample (sample number 24$)$ (2.63\% over the total), which is therefore above the maximum allowed by law, $5 \mu \mathrm{g} \mathrm{g}^{-1}$ at most. A maximum value of $7 \mu \mathrm{g} \mathrm{g}^{-1}$ was verified by Kump et al. ${ }^{18}$ in Slovenia honeys, similarly to the value verified in the present study.

The high $\mathrm{Cr}, \mathrm{Ni}$, and $\mathrm{Pb}$ concentrations in the analyzed samples may indicate a possible environmental contamination according to papers by Tong et al. ${ }^{4}$ in U.S.A., Merin et al ${ }^{19}$ in Israel and Braziewiez et al. ${ }^{20}$ in Poland. According to Morse and Lisk ${ }^{16}$, the presence of high contents of $\mathrm{Cd}, \mathrm{Cr}, \mathrm{Co}, \mathrm{Fe}, \mathrm{Ni}, \mathrm{Zn}$, and $\mathrm{Pb}$ in honey samples of several nations, may have as their source a galvanized steel container used in the processing and storage of this product. Tong et al. ${ }^{4}$ observed that the U.S.A. honeys that came into contact with metal containers during processing showed high zinc contents.

$\mathrm{Cu}$ was found at a mean value of $0.179 \mu \mathrm{g} \mathrm{g}^{-1}$ (0.007 to $0.908 \mu \mathrm{g}$ $\left.\mathrm{g}^{-1}\right)$. The value established by Brazilian law for this element is 10.00 $\mu \mathrm{g} \mathrm{g}^{-1}$ maximum; thus, all samples analyzed are in conformity with the law. Values near those in the present study were verified by Marchini et al. ${ }^{21}$ in honey samples from the State of São Paulo; that author obtained values from 0.1 to $2.0 \mu \mathrm{g} \mathrm{g}^{-1}$ for wild flower honey samples. In turn, Nanda et al..$^{22}$ worked with honey of different floral sources from India, and verified $\mathrm{Cu}$ values ranging from 1.74 to 2.9 $\mu \mathrm{g} \mathrm{g}^{-1}$, well above those in the present study.

The following values were obtained for the chemical elements $\mathrm{K}, \mathrm{Ca}, \mathrm{Ti}, \mathrm{Mn}, \mathrm{Fe}, \mathrm{Co}, \mathrm{Br}, \mathrm{Rb}, \mathrm{Sr}, \mathrm{Ba}$, and $\mathrm{Hg}$, which are not covered by Brazilian law: $\mathrm{K}$ was the chemical element with the highest amount as compared with other elements. The mean value found was $109.671 \mu \mathrm{g} \mathrm{g}^{-1}$, varying from 2.180 to $204.77 \mu \mathrm{g} \mathrm{g}^{-1}$. Yilmaz and Yavuz ${ }^{23}$ analyzed honey samples from Turkey and observed a mean value of $296 \mu \mathrm{g} \mathrm{g}^{-1}$ for $\mathrm{K}$, while Nanda et al..$^{22}$ verified values varying from 489.52 to $932.56 \mu \mathrm{g} \mathrm{g}^{-1}$ in Indian honey, well above those observed in the Piauí samples.

An average of $14.471 \mu \mathrm{g} \mathrm{g}^{-1}\left(0.385\right.$ to $\left.76.759 \mu \mathrm{g} \mathrm{g}^{-1}\right)$ was observed for element $\mathrm{Ca}$, which ranked second in amount. Marchini et $a l .^{21}$ found higher values in honey from the State of São Paulo; Ca values varied from 55 to $301 \mu \mathrm{g} \mathrm{g}^{-1}$ for Eucalyptus flower honey, and from 1 to $202 \mu \mathrm{g} \mathrm{g}^{-1}$ for wild flower honey.

Element $\mathrm{Ti}$ was verified in 8 of the samples analyzed (3, 5, 14, $24,25,26,28$, and 29) and a mean value of $0.112 \mu \mathrm{g} \mathrm{g}^{-1}$ was observed ( 0.007 to $\left.0.266 \mu \mathrm{g} \mathrm{g}^{-1}\right)$. Tong et al. ${ }^{4}$ analyzed U.S.A. honey samples collected near mines, industries and highways, and verified Ti values ranging from 0.04 to $3.1 \mu \mathrm{g} \mathrm{g}^{-1}$; therefore, they obtained values well above those observed in the present study.

The mean amount of element Mn was $0.493 \mu \mathrm{g} \mathrm{g}^{-1}$ (0.014 to $\left.1.434 \mu \mathrm{g} \mathrm{g}{ }^{-1}\right)$. Salinas et al. $^{24}$ analyzed honey samples from Spain and determined a mean $\mathrm{Mn}$ value of $0.8 \mu \mathrm{g} \mathrm{g}^{-1}$; this mean is almost twice as high as that verified for the samples under study.

Fe had a mean value of $1.722 \mu \mathrm{g} \mathrm{g}^{-1}$ (0.067 to $\left.7.053 \mu \mathrm{g} \mathrm{g}^{-1}\right)$. Marchini et al. ${ }^{21}$ verified values varying from 2.1 to $9.0 \mu \mathrm{g} \mathrm{g}^{-1}$ in Eucalyptus flower honey samples from the State of São Paulo; these values were a little higher than those verified in the present work.

The element Co was verified in two samples (5.26\%), with values of $0.037 \mu \mathrm{g} \mathrm{g}^{-1}$ (sample 14) and $0.039 \mu \mathrm{g} \mathrm{g}^{-1}$ (sample 24). A research developed by Morse and Lisk ${ }^{16}$ with honey samples from different countries found Co values varying from 0.456 to $0.770 \mu \mathrm{g} \mathrm{g}^{-1}$; these were therefore higher than those verified for Piauí samples.

The mean amount of $\mathrm{Rb}$ was $0.371 \mu \mathrm{g} \mathrm{g}^{-1}\left(0.007\right.$ to $\left.1.528 \mu \mathrm{g} \mathrm{g}^{-1}\right)$. Iskander ${ }^{25}$ verified $\mathrm{Rb}$ values varying from 0.88 to $0.97 \mu \mathrm{g} \mathrm{g}^{-1}$, while Latorre et al. ${ }^{26}$ analyzed honey samples from Spain and evidenced a mean value of $1.5 \mu \mathrm{g} \mathrm{g}^{-1}$, near the upper limit of the amount observed in this work.

Sr was verified in 23 samples ( $60.52 \%$ from total), and a mean value of $0.145 \mu \mathrm{g} \mathrm{g}^{-1}$ (0.006 to $\left.0.5370 \mu \mathrm{g} \mathrm{g}^{-1}\right)$ was observed; these values, however, were low when compared with those by Tong et $a l .{ }^{4}$, who found $\mathrm{Sr}$ values varying from 0.03 to $2.6 \mu \mathrm{g} \mathrm{g}{ }^{-1}$ in U.S.A. 
Table 1. Mean values $\left(\mu \mathrm{g} \mathrm{g}^{-1}\right)$ of chemical elements in 38 samples of Apis mellifera honey from different municipalities of the State of Piauí, Brazil

\begin{tabular}{|c|c|c|c|c|c|c|c|c|c|c|c|c|c|c|c|c|}
\hline Sample & $\mathrm{K}$ & $\mathrm{Ca}$ & $\mathrm{Ti}$ & $\mathrm{Cr}$ & Mn & $\mathrm{Fe}$ & Co & $\mathrm{Ni}$ & $\mathrm{Cu}$ & $\mathrm{Zn}$ & $\mathrm{Se}$ & $\mathrm{Br}$ & $\mathrm{Rb}$ & $\mathrm{Sr}$ & $\mathrm{Ba}$ & $\mathrm{Hg}$ \\
\hline 1 & 40.145 & 3.874 & nd & nd & 0.182 & 0.513 & nd & 0.021 & 0.055 & 0.206 & nd & nd & 0.230 & nd & nd & nd \\
\hline 2 & 131.354 & 11.997 & nd & nd & 0.568 & 3.862 & nd & nd & 0.082 & 10.756 & nd & nd & 0.686 & 0.537 & 11.681 & nd \\
\hline 3 & 159.004 & 18.775 & 0.266 & nd & 0.725 & 2.694 & nd & nd & 0.125 & 0.683 & nd & nd & 0.802 & 0.207 & nd & nd \\
\hline 4 & 163.979 & 76.759 & nd & 0.110 & 0.865 & 1.394 & nd & nd & 0.241 & 0.487 & nd & nd & 0.589 & 0.108 & nd & nd \\
\hline 5 & 144.347 & 21.208 & 0.242 & nd & 1.434 & 4.143 & nd & nd & 0.209 & 0.679 & nd & nd & 0.614 & 0.261 & nd & nd \\
\hline 6 & 140.359 & 16.698 & nd & nd & 0.661 & 1.328 & nd & nd & 0.258 & 0.398 & nd & nd & 0.466 & 0.166 & nd & nd \\
\hline 7 & 161.322 & 30.020 & nd & nd & 0.921 & 3.777 & nd & 0.144 & 0.311 & 0.663 & nd & nd & 0.471 & 0.219 & nd & nd \\
\hline 8 & 58.209 & 12.425 & nd & nd & 0.388 & 0.728 & nd & nd & 0.130 & 3.907 & nd & nd & 0.218 & 0.134 & nd & nd \\
\hline 9 & 123.960 & 10.949 & nd & nd & 0.331 & 1.169 & nd & 3.241 & 0.908 & 6.838 & nd & nd & 0.197 & nd & nd & nd \\
\hline 10 & 174.743 & 18.663 & nd & nd & 0.766 & 4.636 & nd & 0.075 & 0.254 & 1.387 & nd & nd & 0.348 & 0.138 & nd & nd \\
\hline 11 & 163.952 & 19.569 & nd & nd & 0.445 & 7.053 & nd & nd & 0.228 & 0.783 & nd & nd & 0.703 & 0.265 & nd & nd \\
\hline 12 & 46.870 & 9.587 & nd & nd & 0.345 & 1.306 & nd & nd & 0.163 & 0.356 & nd & nd & 0.142 & 0.127 & nd & nd \\
\hline 13 & 138.434 & 19.627 & nd & nd & 0.773 & 2.592 & nd & nd & 0.193 & 0.490 & nd & nd & nd & nd & nd & nd \\
\hline 14 & 103.285 & 14.102 & 0.197 & nd & 0.371 & 2.003 & 0.037 & 0.021 & 0.183 & 0.241 & nd & nd & 0.385 & 0.110 & nd & nd \\
\hline 15 & 123.649 & 15.680 & nd & nd & 0.685 & 2.468 & nd & nd & 0.336 & 0.634 & nd & nd & 0.648 & 0.182 & nd & nd \\
\hline 16 & 152.359 & 17.278 & nd & nd & 0.613 & 1.568 & nd & 0.061 & 0.262 & 0.434 & nd & nd & 0.320 & 0.080 & nd & nd \\
\hline 17 & 101.229 & 10.634 & nd & nd & 0.770 & 1.239 & nd & 0.021 & 0.062 & 0.192 & nd & nd & 0.332 & 0.057 & nd & nd \\
\hline 18 & 128.453 & 18.959 & nd & 0.181 & 0.849 & 2.245 & nd & 0.163 & 0.244 & 0.348 & nd & nd & 0.303 & nd & nd & nd \\
\hline 19 & 123.090 & 11.783 & nd & nd & 0.575 & 1.356 & nd & 0.038 & 0.107 & 0.681 & nd & nd & 0.310 & 0.117 & nd & nd \\
\hline 20 & 87.802 & 9.684 & nd & nd & 0.317 & 1.019 & nd & 0.102 & 0.140 & 0.918 & nd & nd & 0.338 & nd & nd & nd \\
\hline 21 & 50.543 & 6.658 & nd & nd & 0.212 & 0.677 & nd & nd & 0.078 & 0.171 & nd & nd & 0.109 & nd & nd & nd \\
\hline 22 & 69.546 & 6.816 & nd & 0.038 & 0.160 & 0.5 & nd & 0.030 & 0.053 & 0.425 & nd & nd & 0.166 & nd & nd & nd \\
\hline 23 & 82.259 & 13.219 & nd & nd & 0.471 & 0.931 & nd & nd & 0.133 & 0.395 & nd & nd & 0.303 & nd & nd & nd \\
\hline 24 & 12.398 & 2.149 & 0.035 & 0.412 & 0.062 & 0.398 & 0.039 & 7.191 & 0.094 & 0.032 & nd & nd & 0.035 & nd & nd & nd \\
\hline 25 & 21.237 & 3.361 & 0.058 & nd & 0.085 & 0.567 & nd & 0.337 & 0.041 & 0.069 & nd & nd & 0.094 & 0.032 & nd & nd \\
\hline 26 & 8.862 & 1.687 & 0.028 & nd & 0.053 & 0.3 & nd & 0.006 & 0.029 & 0.085 & nd & nd & 0.034 & 0.026 & nd & nd \\
\hline 27 & 204.777 & 22.212 & nd & nd & 1.318 & 1.954 & nd & nd & 0.104 & 0.801 & nd & nd & 0.427 & nd & nd & nd \\
\hline 28 & 2.180 & 0.385 & 0.007 & nd & 0.014 & 0.067 & nd & nd & 0.007 & 0.010 & nd & nd & 0.007 & 0.006 & nd & nd \\
\hline 29 & 31.736 & 4.309 & 0.061 & 0.114 & 0.151 & 0.846 & nd & 1.408 & 0.078 & 0.078 & nd & nd & 0.144 & 0.054 & nd & nd \\
\hline 30 & 106.820 & 13.988 & nd & nd & 0.479 & 1.698 & nd & 0.122 & 0.257 & 0.391 & nd & nd & 0.185 & nd & nd & nd \\
\hline 31 & 183.062 & 14.435 & nd & nd & 0.296 & 0.862 & nd & nd & 0.145 & 0.333 & nd & nd & 0.423 & nd & nd & nd \\
\hline 32 & 203.133 & 19.678 & nd & nd & 0.467 & 2.027 & nd & 0.091 & 0.208 & 0.310 & nd & nd & 0.433 & nd & nd & nd \\
\hline 33 & 113.789 & 9.567 & nd & nd & 0.258 & 1.427 & nd & nd & 0.070 & 0.326 & nd & nd & 0.313 & nd & nd & nd \\
\hline 34 & 129.765 & 11.836 & nd & nd & 0.341 & 1.439 & nd & 0.102 & 0.269 & nd & nd & nd & 1.528 & 0.136 & nd & nd \\
\hline 35 & 138.828 & 11.846 & nd & nd & 0.451 & 1.724 & nd & 0.026 & 0.160 & 0.358 & nd & nd & 0.456 & 0.136 & nd & nd \\
\hline 36 & 132.732 & 13.036 & nd & nd & 0.618 & 0.875 & nd & 0.036 & 0.224 & 0.634 & nd & nd & 0.461 & 0.147 & nd & nd \\
\hline 37 & 140.107 & 16.643 & nd & 0.322 & 0.399 & 1.313 & nd & 2.669 & 0.222 & 0.141 & nd & nd & 0.373 & 0.094 & nd & nd \\
\hline 38 & 69.169 & 9.801 & nd & nd & 0.303 & 0.642 & nd & 0.112 & 0.125 & 0.127 & nd & nd & 0.147 & nd & nd & nd \\
\hline
\end{tabular}

nd - not detected

honey samples near mines, industries, and highways.

Ba was verified in a single sample (sample no. 2$)(2.63 \%$ from total) $\left(11.681 \mathrm{~g} \mathrm{~g} \mathrm{~g}^{-1}\right)$. Lower values than those verified in this work were observed by Lasceve and $\operatorname{Gonnet}^{27}\left(0.005\right.$ to $\left.0.4 \mu \mathrm{g} \mathrm{g}^{-1}\right)$ in honey samples of France and Hungary.

\section{Cluster analysis for chemical elements}

In the principal components cluster analysis for 38 honey samples from the State of Piauí and for 14 chemical elements (Table 1), 12 were selected and 2 ( $\mathrm{Ni}$ and $\mathrm{Zn}$ ) were discarded, since they were highly correlated.

Variance estimate results (eigenvalues) are presented in Table 4.

From Table 4 it can be observed that the first component concentrated $30.75 \%$ of total variance, the second $47.90 \%$, the third $62.32 \%$, and the fourth $76.41 \%$. It is noted that four principal components were required to explain $70 \%$ of total available variance among chemical elements, and thus considerable variance dispersion can be verified in the material studied.

Figure 1 show a phenogram prepared from the mean Euclidean distance and the UPGMA method, involving the 38 honey samples and chemical elements.

The criterion adopted to define groups was the linkage distances graph in the successive cluster analysis steps (Figure 2). This method is based on the identification of a plateau in the vertical direction, which means that many groups were formed at the same linkage distance; this distance is an optimal cutoff point on the phenogram and determines the number of groups formed. The cutoff point selected in this work was 18 , represented by the horizontal line in Figure 1 and by the arrow in Figure 2 .

From the phenogram (Figure 1) of samples studied, it can be observed that 9 groups were formed. Group 1 has 1 sample (Number 4); group 2 has 2 samples (Numbers. 32 and 27); group 3 has 2 samples (Numbers. 31 and 10); group 4 has 4 samples (Numbers 7 , 16, 11, and 3); group 5 has 4 samples (Numbers. 33, 17, 30, and 14); group 6 has 12 samples (Numbers 35, 13, 37, 6, 5, 36, 34, 18, 
Table 2. Botanical origin of 38 Apis mellifera honey samples from different municipalities in the State of Piauí, Brazil

\begin{tabular}{|c|c|c|}
\hline \multirow[t]{2}{*}{ Sample } & \multicolumn{2}{|c|}{ Botanical origin } \\
\hline & Scientific name & Popular name \\
\hline 1 & Mimosa verrucosa & Jurema \\
\hline 2 & Mimosa verrucosa & Jurema \\
\hline 3 & Piptadenia sp. & Angico-de-bezerro \\
\hline 4 & Piptadenia sp. & Angico-de-bezerro \\
\hline 5 & Piptadenia sp. & Angico-de-bezerro \\
\hline 6 & Piptadenia sp. & Angico-de-bezerro \\
\hline 7 & Piptadenia sp. & Angico-de-bezerro \\
\hline 8 & Piptadenia sp. & Angico-de-bezerro \\
\hline 9 & Mimosa caesalpineaefolia & Sansão-do-campo \\
\hline 10 & Piptadenia $\mathrm{sp}$ & Angico-de-bezerro \\
\hline 11 & Mimosa caesalpineaefolia & Sansão-do-campo \\
\hline 12 & $\begin{array}{c}\text { Salvia sp.+Tibouchina } \\
\text { sp.+Croton sp. }\end{array}$ & $\begin{array}{l}\text { Salvia + Quaresmeira } \\
+ \text { Marmeleiro }\end{array}$ \\
\hline 13 & Piptadenia sp. & Angico-de-bezerro \\
\hline 14 & Piptadenia $\mathrm{sp}$. & Angico-de-bezerro \\
\hline 15 & Piptadenia sp. & Angico-de-bezerro \\
\hline 16 & Piptadenia sp. & Angico-de-bezerro \\
\hline 17 & Piptadenia sp. & Angico-de-bezerro \\
\hline 18 & Piptadenia sp. & Angico-de-bezerro \\
\hline 19 & $\begin{array}{c}\text { Piptadenia sp.+ } \\
\text { Borreria verticillata }\end{array}$ & $\begin{array}{l}\text { Angico-de-bezerro + } \\
\text { Vassourinha-de-botão }\end{array}$ \\
\hline 20 & Mimosa verrucosa & Jurema \\
\hline 21 & Piptadenia sp. & Angico-de-bezerro \\
\hline 22 & $\begin{array}{l}\text { Piptadenia } \mathrm{sp} . \\
\text { +Richardia } \mathrm{sp} .\end{array}$ & $\begin{array}{c}\text { Angico-de-bezerro } \\
+ \text { Poaia }\end{array}$ \\
\hline 23 & Piptadenia sp. & Angico-de-bezerro \\
\hline 24 & Piptadenia sp. & Angico-de-bezerro \\
\hline 25 & Croton urucurana & Sangra d'água \\
\hline 26 & Piptadenia sp. & Angico-de-bezerro \\
\hline 27 & Piptadenia sp. & Angico-de-bezerro \\
\hline 28 & Tibouchina sp.+ & Quaresmeira + \\
\hline 29 & $\begin{array}{c}\text { Mimosa caesalpineaefolia } \\
\text { Polifloral }\end{array}$ & Sansão-do-campo \\
\hline 30 & Piptadenia sp. & Angico-de-bezerro \\
\hline 31 & Piptadenia sp. & Angico-de-bezerro \\
\hline 32 & Piptadenia sp. & Angico-de-bezerro \\
\hline 33 & Piptadenia sp. & Angico-de-bezerro \\
\hline 34 & Piptadenia sp. & Angico-de-bezerro \\
\hline 35 & Piptadenia sp. & Angico-de-bezerro \\
\hline 36 & Piptadenia sp. & Angico-de-bezerro \\
\hline 37 & Piptadenia sp. & Angico-de-bezerro \\
\hline 38 & Piptadenia sp. & Angico-de-bezerro \\
\hline
\end{tabular}

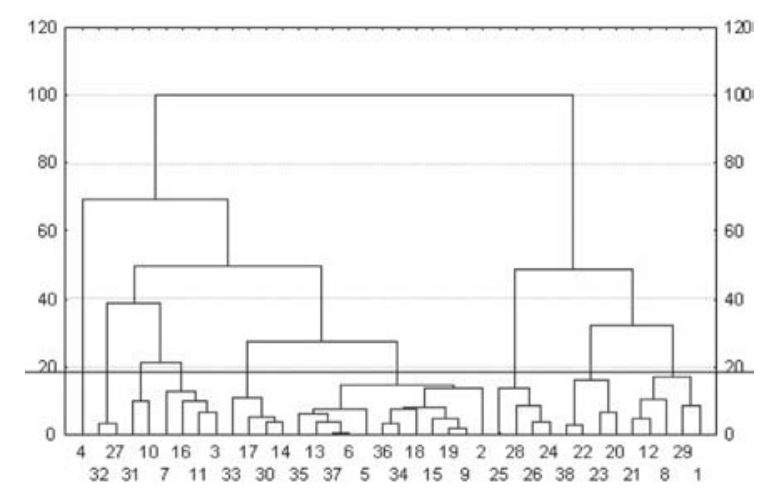

Figure 1. Phenogram obtained by cluster analysis, using mean Euclidean distance and the UPGMA method for 38 Apis mellifera honey samples from the State of Piaui and 12 selected chemical elements
Table 3. Values established by Brazilian law, mean value, confidence interval (5\%), and minimum and maximum values for chemical elements found in 38 Apis mellifera honey samples from different municipalities in the State of Piauí, Brazil

\begin{tabular}{lcccc}
\hline $\begin{array}{l}\text { Chemical } \\
\text { Elements } \\
\mu \mathrm{g} \mathrm{g}^{-1}\end{array}$ & $\begin{array}{c}\text { Brazilian } \\
\text { Law }^{14,15}\end{array}$ & Mean & Minimum & Maximum \\
\hline $\mathrm{K}$ & & & & \\
$\mathrm{Ca}$ & - & $109.671 \pm 17.487$ & 2.180 & 204.777 \\
$\mathrm{Ti}$ & - & $14.471 \pm 3.8797$ & 0.385 & 76.759 \\
$\mathrm{Cr}$ & $<0.10^{15}$ & $0.112 \pm 0.07$ & 0.007 & 0.266 \\
$\mathrm{Mn}$ & - & $0.493 \pm 0.103$ & 0.014 & 1.434 \\
$\mathrm{Fe}$ & - & $1.722 \pm 0.446$ & 0.067 & 7.053 \\
$\mathrm{Co}$ & - & 0.038 & 0.037 & 0.039 \\
$\mathrm{Ni}$ & $<5.00^{15}$ & $0.728 \pm 0.706$ & 0.006 & 7.191 \\
$\mathrm{Cu}$ & $<10.00^{14}$ & $0.179 \pm 0.0471$ & 0.007 & 0.908 \\
$\mathrm{Zn}$ & $<50.00^{15}$ & $0.967 \pm 0.653$ & 0.010 & 10.756 \\
$\mathrm{Se}$ & $<0.30^{15}$ & nd & nd & nd \\
$\mathrm{Br}$ & - & nd & nd & nd \\
$\mathrm{Rb}$ & - & $0.371 \pm 0.097$ & 0.007 & 1.528 \\
$\mathrm{Sr}$ & - & $0.145 \pm 0.045$ & 0.006 & 0.537 \\
$\mathrm{Ba}$ & - & $11.681^{*}$ & - & - \\
$\mathrm{Hg}$ & - & nd & nd & nd \\
\hline
\end{tabular}

nd: not detected; * presence in only one sample

Table 4. Variance estimates (eigenvalues) and cumulative percentage of total variance $(\%)$ obtained by principal components analysis, considering 38 honey samples from Piauí, Brazil and 12 chemical elements

\begin{tabular}{ccc}
\hline Principal components & Eigenvalues & \% Accumulated \\
\hline $\mathrm{Y}_{1}$ & 4.3045 & 30.75 \\
$\mathrm{Y}_{2}$ & 2.4021 & 47.90 \\
$\mathrm{Y}_{3}$ & 2.0185 & 62.32 \\
$\mathrm{Y}_{4}$ & 1.9728 & 76.41 \\
\hline
\end{tabular}

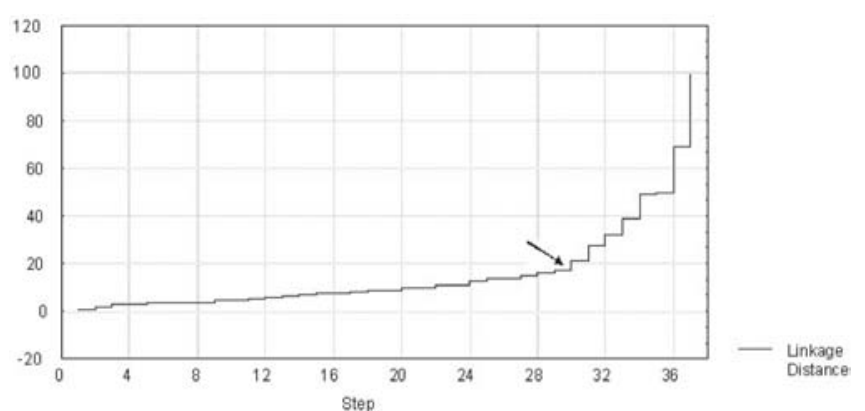

Figure 2. Linkage distance graph in successive clustering steps using the mean Euclidean distance and the UPGMA method. The arrow indicates the cutoff distance in the phenogram which defines groups in Figure 1

15, 19, 9, and 2); group 7 has 4 samples (Numbers. 25, 28, 26, and 24), group 8 has 4 samples (Numbers 38, 22, 23, and 20), and group 9 has 5 samples (Numbers 21, 12, 29, and 1).

Of the chemical elements analyzed for each axis (Table 5), those that contributed the most for the formation of groups on the $\mathrm{X}$ axis were $\mathrm{Rb}$ and $\mathrm{K}$, and $\mathrm{Hg}$ and $\mathrm{Ni}$ on the $\mathrm{Y}$ axis.

By analyzing Table 1 and Figure 1 it is verified that a relation exists between groups and concentrations of element $\mathrm{K}$. The groups 
Table 5. Eigenvalues calculated for 38 honey samples from the State of Piauí, Brazil analyzed for chemical elements

\begin{tabular}{ccc}
\hline Chemical elements & X Axis & Y Axis \\
\hline $\mathrm{K}$ & $\mathbf{0 . 3 7 8 5 3 9}$ & -0.016030 \\
$\mathrm{Ca}$ & 0.279348 & -0.052895 \\
$\mathrm{Ti}$ & 0.096824 & -0.036901 \\
$\mathrm{Cr}$ & -0.172490 & 0.253550 \\
$\mathrm{Mn}$ & 0.362567 & -0.095835 \\
$\mathrm{Fe}$ & 0.373555 & 0.026136 \\
$\mathrm{Co}$ & -0.157498 & 0.217562 \\
$\mathrm{Ni}$ & -0.208573 & $\mathbf{0 . 4 6 2 0 0 4}$ \\
$\mathrm{Cu}$ & 0.145908 & 0.417868 \\
$\mathrm{Zn}$ & 0.200347 & 0.430989 \\
$\mathrm{Se}$ & - & \\
$\mathrm{Br}$ & $-\overline{\mathbf{0 1 3 2 2 5}}$ & -0.020303 \\
$\mathrm{Rb}$ & 0.359073 & 0.110008 \\
$\mathrm{Sr}$ & 0.197784 & 0.223941 \\
$\mathrm{Ba}$ & 0.002136 & $\mathbf{0 . 4 8 7 4 6 1}$ \\
$\mathrm{Hg}$ & 0.034531 & 0.013658 \\
$\mathrm{~Pb}$ & & \\
\hline
\end{tabular}

and $\mathrm{K}$ concentrations for the samples studied are distributed as follows: group $1\left(163.97 \mu \mathrm{g} \mathrm{g}^{-1}\right)$; group 2 (203.13 to $\left.204.77 \mu \mathrm{g} \mathrm{g}^{-1}\right)$; group 3 (174.74 to $\left.183.06 \mu \mathrm{g} \mathrm{g}^{-1}\right)$; group 4 (152.3 to $163.95 \mu \mathrm{g} \mathrm{g}^{-1}$ ); group 5 (101.22 to $113.78 \mu \mathrm{g} \mathrm{g}^{-1}$ ); group 6 (123.09 to $144.34 \mu \mathrm{g} \mathrm{g}^{-1}$ ); group 7 (2.18 to $\left.21.23 \mu \mathrm{g} \mathrm{g}^{-1}\right)$; group 8 (69.16 to $\left.87.80 \mu \mathrm{g} \mathrm{g}^{-1}\right)$, and group 9 ( 31.73 to $\left.58.20 \mu \mathrm{g} \mathrm{g}^{-1}\right)$.

In honey, $\mathrm{K}$ is the chemical element found at the highest concentration. Crane ${ }^{28}$ reported that honey contains more $\mathrm{K}$ than any other chemical element; this author also mentioned that the amount of $\mathrm{K}$ is 100 times higher than the amount of Fe.

\section{CONCLUSION}

Chemical elements with levels above those established by Brazilian law occurred in the analyzed samples for $\mathrm{Cr}(13.15 \%$ of samples) and $\mathrm{Ni}$ (2.63\% of samples), thus disqualifying these samples.

Elements $\mathrm{K}, \mathrm{Rb}$, and $\mathrm{Hg}$ must be studied in more detail and included in the legislation, since they have great influence on product quality.

\section{REFERENCES}

1. Nobre, A. L. da R.; Tese de Doutorado, Universidade de São Paulo, Brasil, 1990.

2. Louveaux, J.; Cahiers de Nutrition et de Diétetique 1985, 1, 57.

3. Nürnberg, H. W.; Pure Appl. Chem. 1982, 54, 853.

4. Tong, S. S. C.; Morse, R. A.; Bache, C. A.; Lisk, D. J.; Arch. Environ. Health 1975, 30, 329.

5. Nürnberg, H. W.; Analysis Chimie Acta 1984, 164, 1.

6. Caroli, S.; Forte, G.; Lamiceli, A. L.; Galoppi, B.; Talanta 1999, 50, 327.

7. Pregnolato, W.; Pregnolato, N. P., coords.; Normas analíticas do Instituto Adolfo Lutz, $3^{\mathrm{a}}$ ed., Instituto Adolfo Lutz: São Paulo, 1985.

8. Ward, A. F.; Marciello, L. F.; Carrara, L.; Luciano, V. J.; Spectrosc. Lett. 1980, 13, 803 .

9. SAS Institute; SAS/STAT: user's guide - version 6. 4, Ed. Cary, 1990.

10. Mardia, L. V.; Keni, J. T.; Bibby, J. M.; Multivariate analysis, Academic Press: London, 1979

11. Morrison, D. F.; Multivariate statistical methods, $2^{\text {nd }}$ ed., Mc Grow Hill: Tokyo, 1981.

12. Joliffe, I. T.; Applicant Statistical 1973, 21, 21 .

13. Cruz, C. D.; Regazzi, A. J. Modelos biométricos aplicados ao melhoramento genético, Universidade Federal de Viçosa: Viçosa, 1997.

14. http://e-legis.bvs.br/leisref/public/showAct.php?id=22, acessada em Agosto 2006.

15. http://e-legis.bvs.br/leisref/public/showAct.php?id=90\#', acessada em Agosto 2006.

16. Morse, R. A.; Lisk, D. J.; Am. Bee J. 1980, 120, 522.

17. Caroli, S.; Forte, G.; Alessandrelli, M.; Cresti, R.; Spagnoli, M.; D'Ilioss, S.; Pouwels, J.; Kramer, G. N.; Microchem. J. 2000, 67, 227.

18. Kump, P.; Necemer, M.; Snajder, J.; Spectrochim. Acta, Part B 1996, 51, 499.

19. Merin, U.; Bernstein, S.; Rosenthal, I. A.; Food Chem. 1998, 63, 241.

20. Braziewiez, J.; Fijal, I.; Czyewski, T.; Nucl. Instrum. Methods Phys. Res., Sect. A 2002, 487, 231.

21. Marchini, L. C.; Moreti, A. C. C. C.; Otsuk, I. P.; Ciênc. Tecnol. Aliment. $\mathbf{2 0 0 5}, 25,8$.

22. Nanda, V.; Sarkar, B. C.; Sharma, H. K.; Bawa, A. S.; J. Food Composition and Analysis 2003, 16, 613

23. Yilmaz, H.; Yavuz, O.; Food Chem. 1998, 65, 475.

24. Salinas, F.; Montero de Espanha, F.; Osório, E.; Revista Espanhola de Ciencias y Tecnologia de Alimentos 1994, 34, 441.

25. Iskander, F. Y.; Sci. Total Environ. 1996, 192, 119.

26. Latorre, M. J.; Peña, R.; Pita, C.; Botana, A.; García, S.; Herrero, C.; Food Chem. 1999, 66, 263.

27. Lasceve, G.; Gonnet, M.; Apidologie 1974, 5, 201.

28. Crane, E.; Livro do mel, trad. de Astrid Kleinert Giovannini, Nobel: São Paulo, 1983. 